\title{
SELECTION OF PEPPER ACCESSIONS WITH ORNAMENTAL POTENTIAL ${ }^{1}$
}

\author{
GÉRSON DO NASCIMENTO COSTA ${ }^{2 *}$, BRUNA MARIA PRADO DA SILVA ${ }^{2}$, ÂNGELA CELIS DE ALMEIDA \\ LOPES $^{3}$, LEONARDO CASTELO BRANCO CARVALHO ${ }^{3}$, REGINA LUCIA FERREIRA GOMES 3
}

\begin{abstract}
Ornamental plants are all plants grown for their beauty, and are commonly used in gardening and landscaping. The colorful fruits and varied foliage colors that typify ornamental peppers provide a vibrant garden display that rivals other ornamental plants. This study aimed to evaluate the potential ornamental use of eight pepper accessions, Capsicum annuum, from the Capsicum Germplasm Bank of the Universidade Federal do Piauí, using qualitative and quantitative descriptors. The experiment was carried out in a greenhouse at the Department of Plant Science, Centre of Agricultural Sciences of Universidade Federal do Piauí, where the accessions were evaluated through a completely randomized design, with eight replicates, one plant per plot, and characterized based on 35 descriptors, 23 of which were qualitative and 12 quantitative. Data on quantitative descriptors were submitted to univariate analysis of variance, followed by Scott-Knott clustering test at 5\% probability. Data on qualitative multicategorical descriptors were considered based on observations of statistical mode. The eight accessions evaluated have ornamental potential and are within the standards established by the Instituto Brasileiro de Floricultura. The accessions BAGC 98, 100, 203, 207, 224, and 236 accessions are suitable for cultivation in pots, while BAGC 220 is suitable for garden cultivation. BAGC 199 is the most promising accession because it supports all quality criteria required for size, foliage, flowers, and fruit proposed by the Veiling Holambra Cooperative.
\end{abstract}

Keywords: Colors. Morphological descriptors. Fruits. Germplasm.

\section{SELEÇÃO DE ACESSOS DE PIMENTA COM POTENCIAL ORNAMENTAL}

RESUMO - Planta ornamental é toda aquela cultivada por sua beleza e que normalmente é usada em jardinagem e paisagismo. A variada cor da folhagem e os frutos coloridos que caracterizam as pimentas ornamentais garantem uma exibição vívida e brilhante em jardins que rivaliza com outras ornamentais. No presente estudo, objetivou-se avaliar o potencial uso ornamental de oito acessos de pimenta, Capsicum annuum, procedentes do Banco Ativo de Germoplasma de Capsicum (BAGC) da Universidade Federal do Piauí (UFPI) por meio de descritores qualitativos e quantitativos. $\mathrm{O}$ experimento foi conduzido em telado, localizado no Departamento de Fitotecnia, do Centro de Ciências Agrárias, da UFPI, onde os acessos foram avaliados em delineamento inteiramente ao acaso, com oito repetições, sendo uma planta por parcela, e caracterizados com base em 35 descritores, sendo 23 qualitativos multicategóricos e 12 quantitativos. Os dados dos descritores quantitativos foram submetidos à análise de variância univariada, seguida do agrupamento das médias por meio do teste de Scott-Knott, a 5\% de probabilidade, já os dados dos descritores qualitativos multicategóricos foram ponderados a partir da moda observada. Os oito acessos avaliados possuem potencial ornamental e estão dentro dos padrões estabelecidos pelo Instituto Brasileiro de Floricultura, sendo que os acessos BAGC 98, 100, 203, 207, 224 e 236 foram adequados para o cultivo em vasos, enquanto que BAGC 220, para cultivo em jardins. O acesso BAGC 199 destacou-se como o mais promissor por corresponder a todos os critérios de qualidade para porte, folhagem, flores e frutos propostos pela Cooperativa Veiling Holambra.

Palavras-chave: Cores. Descritores morfológicos. Frutos. Germoplasma.

\footnotetext{
${ }^{*}$ Corresponding author

${ }^{1}$ Received for publication in $07 / 18 / 2018$; accepted in $02 / 05 / 2019$.

Extracted from the master dissertation of the first author.

${ }^{2}$ Graduate Program in Genetics and Breeding, Universidade Federal do Piauí, Teresina, PI, Brazil; gerson.nascimento@live.com - ORCID: 0000-0002-3040-2292, brunampsilva@gmail.com - ORCID: 0000-0002-3488-9093.

${ }^{3}$ Department of Plant Science, Universidade Federal do Piauí, Teresina, PI, Brazil; acalopes@ufpi.edu.br - ORCID: 0000-0002-9546-5403, cbcleonardo@gmail.com - ORCID: 0000-0001-5722-9322, rlfgomes@ufpi.edu.br - 0000-0002-7700-6959.
} 


\section{INTRODUCTION}

Ornamental plants are all plants grown for their beauty and comprise potted and cutting flowers, shrub, and tree species, which are usually used in gardening and landscaping (IBRAFLOR, 2018). The annual turnover for all aspects of floriculture is estimated at more than 300 billion dollars (CHANDLER; SANCHEZ, 2012); however, the ornamental market lacks novelty, and new products add competitiveness to the sector and considerably increase the profit margin.

The cultivation, marketing, and interest in ornamental peppers have increased worldwide. (STOMMEL; BOSLAND, 2005; FINGER et al., 2012), encouraging vegetable breeding studies, especially for use in landscaping. According to Ari et al., (2016), ornamental peppers (Capsicum annuum L.) have the advantage of polyvalent use, i.e., they can also be used fresh (in natura), such as in spices or pickled. These plants can be cultured in small vessels, they adorn gardens, and when cut, some species are used in flower arrangements. However, in landscaping, ornamental peppers can have a larger size (up to $1 \mathrm{~m}$ ) (WITT, 1999).

Variation in foliage color and the colorful and bright fruits mean that the peppers can rival other important ornamental plants such as chrysanthemum (Dendranthema grandiflora Tzvelev) (STOMMEL; GRIESBACH, 2005). Silva et al. (2015) highlighted that peppers with decorative features represent a trend in the landscaping market in Brazil. Conversely, Backes et al., (2007) reported that studies on the production of ornamental pepper are limited, even though it has good acceptance in the market

The morphological diversity of Capsicum is an essential attribute sought by the ornamental plant market (STOMMEL; GRIESBACH, 2005). Capsicum annuum is the most cultivated species of Capsicum, with the greatest genetic variability in relation to the other domesticated species (RÊGO et al., 2012). However, few commercial varieties are intended for ornamentation in the country (VASCONCELOS et al., 2012).

In Brazil, are commercialized by Isla Sementes, the ornamental peppers: Espaguetinho, Pirâmide, Etna, and Stromboli (ISLA, 2018); however, foreign varieties can also be found in virtual seed shops and more rarely, in flower shops. These include Prairie Fire, Explosive Ember, Sangria, Calypso, Numex Centennial, Garda
Tricolore, Black Pearl, Black Olive, Purple Flash, and Cajun Belle pepper.

Diversity of the genus Capsicum, associated with the few ornamental peppers available on the market, have stimulated pepper breeding programs in search of plants with higher production, resistance to diseases and pests, fruit quality, and potential for ornamentation. However, to conduct such programs, it is important to maintain, conserve, and characterize the genetic diversity of accessions present in germplasm banks. (SUDRÉ et al., 2006, RÊGO et al., 2012).

Evaluation of the ornamental potential of pepper accessions present in germplasm banks is important as it generates data on the conserved materials and provides information to stimulate their effective utilization in the floriculture sector, and to assist future breeding programs in the development of new ornamental pepper cultivars (MELO et al., 2014).

This study aimed to evaluate the potential ornamental use of eight pepper accessions, $C$. annuum, from the Capsicum Germplasm Bank of the Universidade Federal do Piauí, using qualitative and quantitative descriptors.

\section{MATERIAL AND METHODS}

The experiment was carried out in a greenhouse, (50\% shading), at the Department of Plant Science, Centre of Agricultural Sciences of Universidade Federal do Piauí, in the municipality of Teresina - Piauí state, Brazil, located at an altitude of $72.7 \mathrm{~m}, 05^{\circ} 05^{\prime} 05^{\prime \prime}$ latitude $\mathrm{S}$ and $42^{\circ} 05^{\prime}$ longitude $\mathrm{W}$, from February to November 2017. Eight pepper accessions, with ornamental potential, were obtained (Table 1) from the Active Germplasm Bank of Capsicum (BAGC), of Universidade Federal do Piauí (UFPI), derived from the Northeast region of Brazil.

The accessions were seeded in expanded polystyrene trays with 128 cells, containing Plantmax ${ }^{\circledR} \quad$ commercial substrate. Seedlings presenting six to eight true leaves were transplanted into polyethylene vessels (size 20,15 L), containing substrate with part vegetable soil and part humus. Fertilization was performed with $2 \mathrm{~g}$ of ammonium sulfate, $17 \mathrm{~g}$ of single superphosphate, and $2.5 \mathrm{~g}$ of potassium chloride, as recommended by Alcântara and Ribeiro (2008). 
Table 1. Identification of eight pepper accessions (Capsicum annuum) with ornamental potential, from the Active Germplasm Bank of Capsicum.

\begin{tabular}{ccc}
\hline Accessions & Common name & State of origin \\
\hline BAGC 236 & Pimenta-de-mesa & Piauí \\
BAGC 98 & Ornamental laranja & Piauí \\
BAGC 100 & Ornamental vermelha & Piauí \\
BAGC 224 & Ornamental vermelha & Maranhão \\
BAGC 203 & Pimenta-de-mesa & Paraíba \\
BAGC 220 & Pimenta vermelha & Paraíba \\
BAGC 207 & Ornamental amarela & Ceará \\
BAGC 199 & Ornamental roxa & Ceará
\end{tabular}

The accessions were evaluated through a completely randomized design, with eight replications and one plant per plot. The morphoagronomic characterization of the accessions was based on the descriptors established by the International Plant Genetic Resources Institute for the genus Capsicum (IPGRI, 1995), and in the Ornamental Pepper Classification Criteria of the Veiling Holambra Cooperative, which are quality standards established nationally by the Instituto Brasileiro de Floricultura (IBRAFLOR, 2018).

In total, 35 descriptors were evaluated; 23 were qualitative multicategorical and 12 were quantitative. The quantitative descriptors were: number of days to flowering (NDF), number of days to maturation (NDM), plant height (PHT), fruit pedicel length (FPL), number of fruits per plant (NFP), fruit persistence (FPS), fruit length (FLC), fruit width (FWL), fruit weight (FWP), number of seeds per fruit (NSF), leaf length (LLC), and vegetable canopy width (VCW).

The qualitative multicategorical descriptors evaluated were: number of flowers per axil, plant architecture, leaf shape, leaf color, leaf pubescence, leaf density, nodal anthocyanin, calyx annular constriction, flower position, corolla shape, corolla color, corolla spot color, anther color, fruit position, fruit color at the intermediate stage, fruit color at the mature stage, fruit shape, fruit shape at blossom end, fruit surface, firmness, and sustentation of stem, stem color, stem shape, and species.

The IPGRI descriptors used to meet the quality criteria of the Veiling Holambra Cooperative for ornamental peppers were: NDF, PHT, NFP, plant architecture, leaf density, and fruit position. In relation to the published literature, the descriptors vegetable canopy width (VCW), firmness, and sustentation of stem (FSS) were unpublished for the characterization of Capsicum, and the descriptor fruit pedicel length (FPL), was unpublished for evaluation of the ornamental potential of peppers. VCW was measured in centimeters and FSS was observed in mature plants, and classified as zero (0), in the absence of firmness or sustentation of the stems (plant with tutoring), and as one (1), when stems were firm (without the need for tutoring).

Data on the quantitative descriptors were submitted to univariate analysis of variance, followed by Scott-Knott clustering test at 5\% probability (SCOTT; KNOTT, 1974), using the GENES software (CRUZ, 2006). Conversely, data on qualitative multicategorical descriptors were considered from observations of the statistical mode, whereas amodal and bimodal decorative traits were also described for a better characterization of accessions and to note the presence of phenotypes important for ornamentation, such as different fruit colors.

\section{RESULTS AND DISCUSSION}

Analysis of variance (Tables 2 and 3) revealed significant differences between pepper accessions for quantitative descriptors, except for number days to flowering (NDM) and fruit persistence (FPS), which indicates variability between the accessions for 10 of the 12 characteristics. The experimental coefficients of variation $(\mathrm{CV})$ ranged from $6.2 \%(\mathrm{NDM})$ to $31.8 \%$ (NFP), and were therefore satisfactory, as significant differences between the accessions were observed for most of the descriptors studied. 
Table 2. Estimates of mean squares (MS) and experimental coefficients of variation (CV) obtained by analysis of variance of six quantitative descriptors of peppers with ornamental potential, from the Active Germplasm Bank of Capsicum.

\begin{tabular}{|c|c|c|c|c|c|c|c|}
\hline \multirow{2}{*}{ S.V } & \multirow{2}{*}{ D.F } & \multicolumn{5}{|c|}{ MS } & \multirow[b]{2}{*}{ FPS } \\
\hline & & $\overline{\mathrm{NDF}}$ & NDM & PHT & FPL & NFP & \\
\hline Treatments & 7 & $452.4^{*}$ & $106.2^{\text {ns }}$ & $126.1^{*}$ & $2.02 *$ & $2484.2^{*}$ & $103.8^{\mathrm{ns}}$ \\
\hline Residual & 24 & 20.6 & 46.5 & 29.7 & 0.13 & 173.3 & 50.8 \\
\hline Total & 31 & & & & & & \\
\hline CV (\%) & & 7.4 & 6.2 & 23.9 & 13.2 & 31.8 & 8.4 \\
\hline
\end{tabular}

Table 3. Estimates of mean squares (MS) and experimental coefficients of variation (CV) obtained by analysis of variance of six quantitative descriptors of peppers with ornamental potential, from the Active Germplasm Bank of Capsicum.

\begin{tabular}{|c|c|c|c|c|c|c|c|}
\hline \multirow[b]{2}{*}{ S.V } & \multirow{2}{*}{ D.F } & \multicolumn{4}{|c|}{ MS } & \multirow[b]{2}{*}{ LLC } & \multirow[b]{2}{*}{ VCW } \\
\hline & & $\overline{\mathrm{LC}}$ & FWL & FWP & $\mathrm{NSF}$ & & \\
\hline Treatments $\mathrm{s}$ & 7 & $4.16^{*}$ & $1.47 *$ & $3.77 *$ & 641.4* & $9.12 *$ & $108.1^{*}$ \\
\hline Residual & 24 & 0.09 & 0.02 & 0.11 & 35.1 & 0.85 & 23.3 \\
\hline Total & 31 & & & & & & \\
\hline $\mathrm{CV}(\%)$ & & 11.3 & 12.7 & 20.5 & 18.5 & 20.6 & 16.6 \\
\hline
\end{tabular}

*Indicates significance at a 0.05 probability level using the F test; S.V - source of variation; D.F - degrees of freedom; FLC - fruit length; FWL - fruit width; FWP - fruit weight; NSF - number of seeds per fruit; LLC - leaf length; VCW vegetable canopy width.

Considering the quantitative descriptors, the results obtained through the clustering of means by the Scott-Knott test (Table 4) indicated that the genotypes were differentiated into four groups for NDF, with the accessions BAGC 220 and 203 being the latest (74 days for flowering) and BAGC 236 and
98 being the most premature (45 and 49 days for flowering, respectively). For NDM, the accessions varied from 100 days (BAGC 236) to 118 days (BAGC 100) to fruit maturity and did not differ statistically, showing uniformity for the precocity of the plants.

Table 4. Means* of 12 quantitative descriptors referring to eight pepper accessions (C. annuum L.) with ornamental potential, from the Active Germplasm Bank of Capsicum.

\begin{tabular}{|c|c|c|c|c|c|c|c|c|c|c|c|c|}
\hline Accessions & $\begin{array}{c}\text { NDF } \\
\text { (days) }\end{array}$ & $\begin{array}{l}\text { NDM } \\
\text { (days) }\end{array}$ & $\begin{array}{l}\text { PHT } \\
(\mathrm{cm})\end{array}$ & $\begin{array}{l}\text { FPL } \\
(\mathrm{cm})\end{array}$ & NFP & $\begin{array}{c}\text { FPS } \\
\text { (days) }\end{array}$ & $\begin{array}{l}\text { FLC } \\
(\mathrm{cm})\end{array}$ & $\begin{array}{l}\text { FWL } \\
(\mathrm{cm})\end{array}$ & $\begin{array}{c}\text { FWP } \\
(\mathrm{g})\end{array}$ & NSF & $\begin{array}{l}\text { LLC } \\
(\mathrm{cm})\end{array}$ & $\begin{array}{c}\mathrm{VC} \\
\mathrm{W} \\
(\mathrm{cm})\end{array}$ \\
\hline BAGC 236 & $45 \mathrm{~d}$ & $100 \mathrm{a}$ & $20.7 \mathrm{~b}$ & $2.1 \mathrm{c}$ & $82 a$ & $89 a$ & $1.1 \mathrm{~d}$ & $0.5 \mathrm{~d}$ & $0.3 \mathrm{c}$ & $20 \mathrm{~d}$ & $1.3 \mathrm{c}$ & $25.7 \mathrm{~b}$ \\
\hline BAGC 98 & $49 d$ & $107 \mathrm{a}$ & $20 \mathrm{~b}$ & $3.1 \mathrm{~b}$ & $14 \mathrm{~b}$ & $82 a$ & $3.5 \mathrm{a}$ & $1.9 \mathrm{a}$ & $2.7 \mathrm{a}$ & $35 b$ & $6 a$ & $33.7 \mathrm{a}$ \\
\hline BAGC 100 & $66 b$ & $118 \mathrm{a}$ & $23 b$ & $2.3 \mathrm{c}$ & $15 b$ & $83 a$ & $3 b$ & $1.9 \mathrm{a}$ & $2.5 \mathrm{a}$ & $31 \mathrm{c}$ & $5.4 \mathrm{a}$ & $31.5 \mathrm{a}$ \\
\hline BAGC 224 & $61 \mathrm{~b}$ & $107 \mathrm{a}$ & $20.7 \mathrm{~b}$ & $2.8 \mathrm{~b}$ & $28 \mathrm{~b}$ & $90 \mathrm{a}$ & $2.7 \mathrm{~b}$ & $2 a$ & $2.9 \mathrm{a}$ & $36 \mathrm{~b}$ & $3.9 \mathrm{~b}$ & $26.2 b$ \\
\hline BAGC 203 & $74 a$ & $114 a$ & $18.3 \mathrm{~b}$ & $1.5 \mathrm{~d}$ & $10 \mathrm{~b}$ & $85 \mathrm{a}$ & $1.5 \mathrm{~d}$ & $1.1 \mathrm{~b}$ & $1.2 \mathrm{~b}$ & $18 \mathrm{~d}$ & $4.8 \mathrm{~b}$ & $23.5 b$ \\
\hline BAGC 220 & $74 a$ & $114 a$ & $36.3 \mathrm{a}$ & $3.8 \mathrm{a}$ & $20 \mathrm{~b}$ & $75 \mathrm{a}$ & $3.9 \mathrm{a}$ & $0.6 \mathrm{~d}$ & $1.4 \mathrm{~b}$ & $38 \mathrm{~b}$ & $6 a$ & $35 \mathrm{a}$ \\
\hline BAGC 207 & $63 b$ & $107 \mathrm{a}$ & $21.3 \mathrm{~b}$ & $3.3 b$ & $29 b$ & $84 a$ & $3.5 \mathrm{a}$ & $0.8 \mathrm{c}$ & $0.9 \mathrm{a}$ & $23 d$ & $3.8 \mathrm{~b}$ & $21.7 \mathrm{~b}$ \\
\hline BAGC 199 & $57 \mathrm{c}$ & $110 \mathrm{a}$ & $21.5 \mathrm{~b}$ & $3 b$ & $82 a$ & $90 \mathrm{a}$ & $2 c$ & $1.1 \mathrm{~b}$ & $1 b$ & $57 \mathrm{a}$ & $4.6 \mathrm{~b}$ & $34 a$ \\
\hline
\end{tabular}

*Means followed by the same letter in the column did not differ significantly from each other, at $5 \%$ probability, by the Scott-Knott test. Descriptors: NDF - number of days to flowering; NDM - number of days to maturation; PHT - plant height; FPL - fruit pedicel length; NFP - number of fruits per plant; FPS - fruit persistence; FLC - fruit length; FWL - fruit width; FWP - fruit weight; NSF - number of seeds per fruit; LLC - leaf length; VCW - vegetable canopy width. 
Eight accessions presented early flowering and fruit maturation, and according to Rêgo et al. (2012), precocity in peppers is an essential criterion for their use in ornamentation. The ornamental peppers Pirâmide, Etna e Stromboli, from the company Isla Sementes, present a mean 100 days for maturation (ISLA, 2018), demonstrating the potential precocity of the BAGC-UFPI accessions.

For PHT, two groups were formed; the accession BAGC 220 had a longer length $(36.3 \mathrm{~cm})$ and the other accessions had height ranging from $18.3 \mathrm{~cm}$ (BAGC 203) to $23 \mathrm{~cm}$ (BAGC 100). Rêgo et al. (2012) noted the importance of evaluating ornamental pepper height and highlighted this aspect for the selection of genotypes aimed the genetic breeding of Capsicum. Nascimento et al. (2015) emphasized that small size of peppers is a requirement of the ornamental plant trade.

Accessions with a small size (6-32 $\mathrm{cm}$ high) can be grown in gardens and in pots; however, taller accessions (height above $80 \mathrm{~cm}$ ) are recommended for garden cultivation. Peppers of the genus Capsicum can be exploited for cultivation in functional gardens, spice gardens, medicinal gardens, and aromatic gardens (NEITZKE et al., 2010; VEILING HOLAMBRA, 2018).

Accessions such as BAGC 220, which are medium to high in size, can be used in landscaping or for cultivation in gardens. (NEITZKE et al., 2010). According to Veiling Holambra (2018), peppers planted in size 20 pots should have a height of $12-44 \mathrm{~cm}$, indicating that even the BAGC 220 accession, with the highest average $(36.3 \mathrm{~cm})$ height, fulfills the ornamentation requirement for commercialization in pots.

Four groups were formed for fruit pedicel length (FPL), with the accession BAGC 220 presenting the highest mean at $3.8 \mathrm{~cm}$, and BAGC 203 presenting the lowest mean at $1.5 \mathrm{~cm}$. Consistent with the findings of FloraHolland (2018), the length of the pedicel in ornamental plants should highlight the flowers of the foliage. Thus, this criterion should be used in peppers, as longer pedicel lengths highlight the peppers to a greater extent in relation to the leaves.

The accessions BAGC 236 and 199 presented the highest mean number of fruits per plant (NFP, 82 fruits), while the number of fruits ranged from 10 (BAGC 203) to 29 (BAGC 207) for the other accessions. There were no significant differences in fruit persistence (FPS), which ranged from 75 (BAGC 230) to 90 days (BAGC 199 and 224). In relation to the number of fruits, the accessions BAGC UFPI are suitable for ornamentation, as they are consistent with Veiling Holambra (2018), who recommended a minimum of 10 fruits for ornamental peppers. However, it was emphasized that, for varieties with larger fruits, a lower number of fruits per potting was sufficient for commercialization, as seen for the variety Calypso. This cooperative still recommends that the fruits present good persistence in the pot but does not define the number of days of persistence.

Four groups were formed for the descriptor fruit length (FLC); the largest fruits belonged to the accession BAGC $220(3.9 \mathrm{~cm})$ and the smaller fruits to the accession BAGC $236(1.1 \mathrm{~cm})$. Four groups were also formed for fruit width (FWL), including BAGC 224, 100, and 98 with wider fruits $(2,1.9$, and $1.9 \mathrm{~cm}$, respectively) and BAGC 236 and 220 , with narrower fruits $(0.5$ and $0.6 \mathrm{~cm}$, respectively).

Three groups were formed for fruit weight (FWP); the accessions BAGC 224, 98, and 100 presented fruits with the highest weights $(2.9,2.7$, and $2.5 \mathrm{~g}$, respectively) and BAGC 236 presented the lightest fruits $(0.3 \mathrm{~g})$. Based on the descriptor number of seeds per fruit (NSF), the accessions differed in four groups, highlighting BAGC 199, which presented highest number of seeds (57 seeds). BAGC 203, 236, and 207 formed a group with the lowest mean NSF, ranging from 18 to 23 seeds per fruit.

Regarding leaf length (LLC), the accessions formed three groups; BAGC 98, 220, and 100 had the largest leaf sizes $(6,6$, and $5.4 \mathrm{~cm}$, respectively), and BAGC 236 had the lowest leaf sizes $(1.3 \mathrm{~cm})$. For vegetable canopy width (VCW), the accessions formed only two groups, ranging from $21.7 \mathrm{~cm}$ (BAGC 207) to $35 \mathrm{~cm}$ (BAGC 220). In relation to these descriptors, Veilling Holambra (2018) does not suggest a specific size for leaves, but warns that the ornamental peppers should present a good cover of leaves, as observed for the accessions presented here.

Through morphological characterization with qualitative multicategorical descriptors, it was possible to evaluate the aesthetic quality of each accession. BAGC 236 (Figure 1a), presented compact architecture, green and lanceolate leaves, high leaf density, and dark purple nodal anthocyanin. This pepper presented white flowers, and erect, and yellow anthers. The fruits are erect and with colors varying from green to dark red with fruits of redmedium color when ripe. The fruits of this accession have a triangular shape and a pointed apex. 


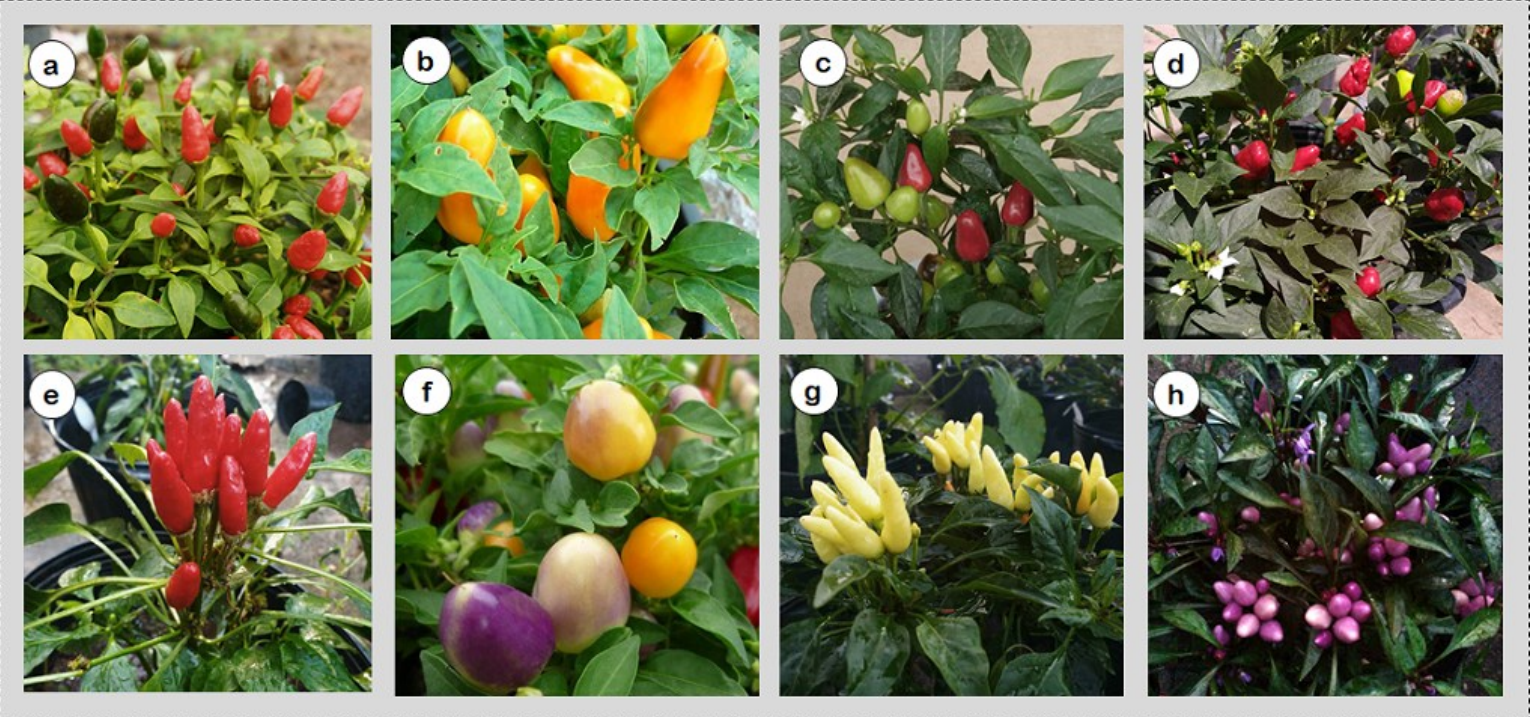

Figure 1. Pepper accessions (C. annuum L.) with ornamental potential from BAGC-UFPI. (a) BAGC 236; (b) BAGC 98; (c) BAGC 100; (d) BAGC 224; (e) BAGC 220; (f) BAGC 203; (g) BAGC 207, and (h) BAGC 199

The accession BAGC 98 (Figure 1b) presented compact architecture with cylindrical and green stems, firm and supported stems, high leaf density, dark green and lanceolate leaves, light purple nodal anthocyanin, white flowers, and pale blue anthers. The fruits are erect, triangular, ranging from green to orange during maturation, have a pointed apex, and a smooth epidermis.

BAGC 100 (Figure 1c), from Piauí state, presented a compact architecture with a cylindrical green stem, which was firm and supported, high leaf density, dark green and lanceolate leaves, purple nodal anthocyanin, white flowers, and blue anthers, with erect and triangular fruits, varying from green to red during maturation. The fruits present a pointed apex and had a smooth texture.

The accession BAGC 224 (Figure 1d), from Maranhão state is very similar to BAGC 100 , but is differentiated by its dark red fruits when ripe and its slightly pointed apex. BAGC 220 (Figure 1e) was erect with a cylindrical green stem, which was firm and supported, intermediate leaf density, green and lanceolate leaves, light purple nodal anthocyanin, white flowers, and pale blue anthers, with erect and elongated fruits, ranging from green to dark red during maturation. The fruits have a pointed apex and a semi-wrinkled texture. The most promising traits of BAGC 220 were its inflorescences and infructescences in bunches, which according to Lorenzi and Souza (2008), are remarkable characteristics in ornamental plants.

The accession BAGC 203 (Figure 1f) was characterized by its compact size and firm stem, which was cylindrical and green, and also by its high leaf density, green or dark green leaves and lanceolate, purple nodal anthocyanin, bunched flowers, white corolla, pale blue anthers, erect fruits, triangular, and smooth, with a slightly pointed apex, suggesting that the fruit be rounded. This accession exhibits purple or green fruits when immature, has several colors during maturation (lilac, yellow, orange), and is red when ripe. The color of the mature fruits is the main highlight of this accession, which was noted by Backes et al., (2007) as one of the main decorative aspects of peppers.

BAGC 207 (Figure 1g) also exhibited a compact architecture, with a firm, cylindrical, green stem, high leaf density with dark green and lanceolate leaves, light purple nodal anthocyanin, bunched flowers, white corolla and yellow anthers, erect fruits, elongated, ranging from yellow to red during maturation, with a pointed apex and semiwrinkled texture.

The accession BAGC 199 (Figure 1h) was characterized by a compact architecture, cylindrical stem, purple color, high leaf density, with leaves that were dark green and/or variegated with purple, lanceolate, purple nodal anthocyanin (Figure 2a), and bunched flowers predominantly purple in color; however, some plants had white flowers with and without purple margins (Figure 2b). All plants had blue anthers. Variation in the color of ornamental pepper flowers is explained by this characteristic having monogenic inheritance with codominant allelic interaction (SANTOS et al., 2013). 


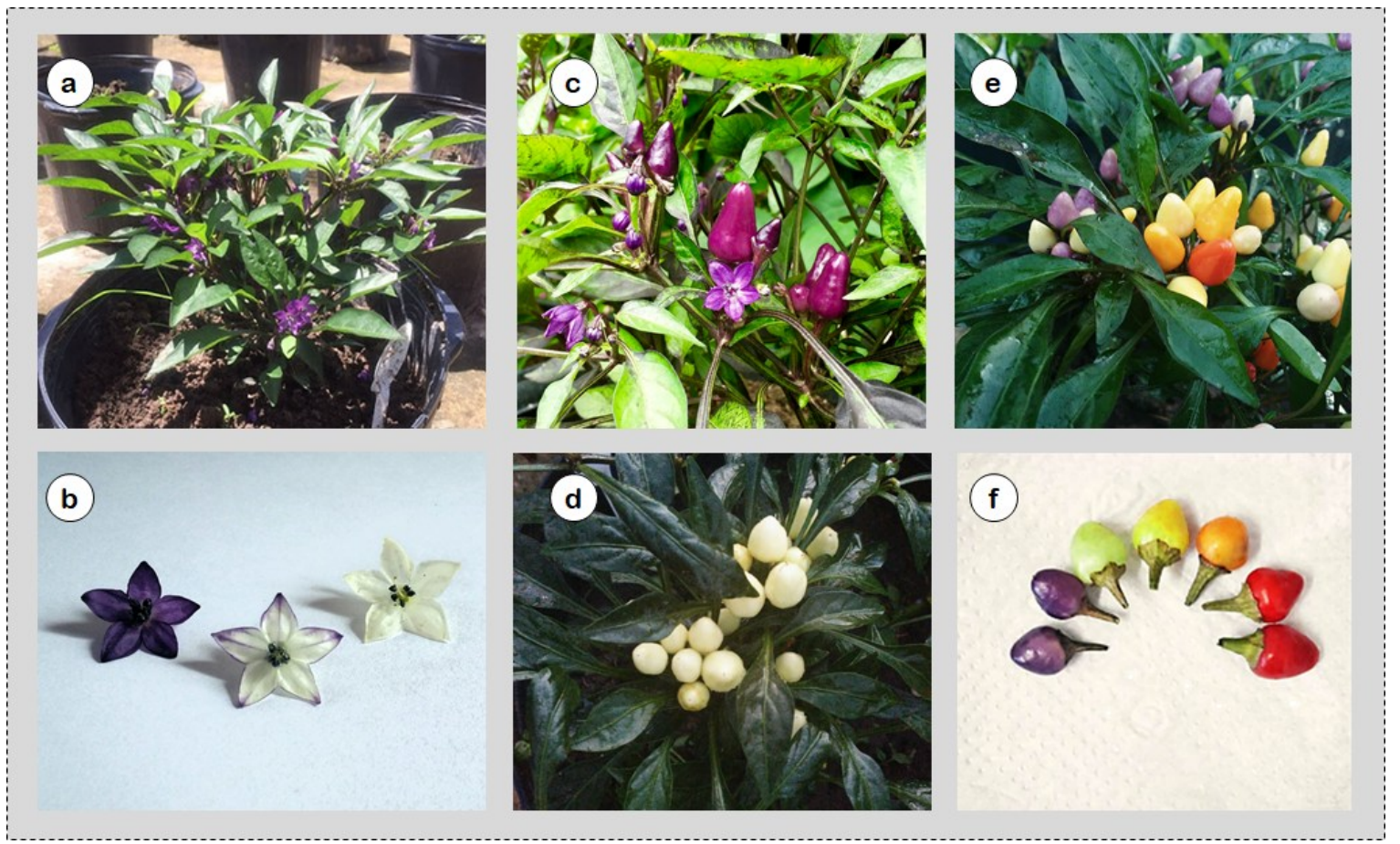

Figure 2. Ornamental traits of the accession BAGC-UFPI 199. (a) Plant at the beginning of flowering has shown by the stem and nodal anthocyanin; (b) corolla colors; (c) purple immature fruits. (d) White immature fruits; (e-f) Different colored fruit during maturation.

BAGC 199 is characterized by erect, triangular fruits, a pointed apex, and a smooth and shiny texture. The fruits are purple (Figure 2c) or white (Figure 2d) when immature, with several colors evident during maturation (lilac, yellow, orange) and dark red when ripe (Figure $2 \mathrm{e}-\mathrm{f}$ ). BAGC 199 shows great promise by presenting flowers and purple fruits, as there is a growing demand for plants with flowers and fruits that are purple, dark purple, and black (STOMMEL; GRIESBACH, 2005).

The presence of nodal anthocyanin, or of this pigment in the whole plant as observed in the BAGC 199 accession, was noted as an ornamental feature by Ari et al., (2016). However, fruits that present different colors during maturation, which contrast with the foliage, are among the most important characteristics of ornamental peppers (CARVALHO et al., 2006).

All eight accessions presented compact plant architecture with high leaf density (except BAGC 220), sparse pubescence, lanceolate leaves, rotated and erect flowers (except BAGC 207), fruits with bright colors, firmness, and stem support, with no need for tutoring, and green cylindrical stems (except BAGC 199).

Neitzke et al. (2010) reported that qualitative descriptors are important for identifying accessions with high ornamental potential, and for use in crosses to obtain ornamental pepper cultivars. The most important qualitative descriptors in relation to aesthetics for evaluating the ornamental potential of peppers were the color of fruits (immature and mature), leaves, and corolla. Later, in a study evaluating the acceptance and preference of consumers for ornamental peppers, Neitzke et al. (2016) found that qualitative characters, compared with quantitative characters, were preferred for ornamental pepper fruits, and that the greatest preference was for plants with fruits contrasting in color in relation to the foliage.

The eight accessions are within the standards set by the Instituto Brasileiro de Floricultura (Ibraflor), which since 2011, recommends the quality standard criteria of the Veiling Holambra Cooperative for the production and marketing of flowers and ornamental plants in Brazil.

The accessions reported herein are adequate for the quality standard of peppers planted in size 20 pots, whose plants must have height of $12-44 \mathrm{~cm}$, dense foliage, good coverage of the vessel, more than 10 fruits per pot, firmness and sustentation of stems, without the need for tutoring, with early flowering, erect fruits that stand out from the foliage, and good persistence in pots.

\section{CONCLUSIONS}

The eight accessions evaluated herein have ornamental potential and are within the standards established by the Instituto Brasileiro de Floricultura.

The accessions BAGC 203, 207, and 236 are small and suitable for cultivation in smaller pots intended for the decoration of internal environments, and can be improved for fruit characteristics such as texture and color; BAGC 98, 100, and 224 are ideal 
for cultivation in pots in outdoor environments, but should be improved in relation to foliage.

Accession BAGC 220 is suitable for cultivation in gardens following breeding for foliage density. BAGC 199, which presented pleasant aesthetics for size, foliage, flowers, and fruits, was suitable for cultivation in pots, and selection to obtain pure lines with flowers and purple fruits, which are current trends in the ornamental peppers market.

\section{ACKNOWLEDGMENTS}

The authors thank the Coordination for Improvement of Higher Education Personnel (CAPES) program for the Master's scholarship awarded to the first author and thank the Universidade Federal do Piauí for providing the necessary infrastructure to execute the work.

\section{REFERENCES}

ARI, E. et al. Comparison of different androgenesis protocols for doubled haploid plant production in ornamental pepper (Capsicum annuum L.). Turkish Journal of Biology, v. 40, n. 4, p. 944-954, 2016.

AlCÂNTARA, F. A.; RIBEIRO, C. S. C. Solos e Adubação: In: RIBEIRO, C. S. C. et al. (Eds.). Pimentas Capsicum. Brasília: Embrapa Hortaliças, 2008. v. 1, cap. 8, p. 81-93.

BACKES, C. et al. Produção de pimenta ornamental em função de substratos e doses de adubação com fertilizantes de liberação lenta e tradicional. Scientia Agraria Paranaensis, v. 6, n. 1-2, p. 67-76, 2007.

CARvalho, S. I. C. et al. Pimentas do gênero Capsicum no Brasil. Brasília, DF: Embrapa Hortaliças, 2006. 27 p. (Documentos, 94).

CHANDLER, S. F., SANCHEZ, C. Genetic modification; the development of transgenic ornamental plant varieties. Plant Biotechnology, v. 10, n. 8 , p. 891-903, 2012.

CRUZ, C. D. Programa Genes: Biometria. 1. ed. Viçosa, MG: Editora UFV, 2006. 382 p.

FINGER, F. L. et al. Produção e potencial de mercado para pimenta ornamental. In: Empresa de Pesquisa Agropecuária de Minas Gerais. (Eds.). Pimentas: do produtor ao consumidor. Belo Horizonte, MG: EPAMIG, 2012. v. 33, n. 267, p. 1420.

\section{FLORAHOLLAND. Product specifications.}

Koninklijke Cooperatieve Bloemenveiling FloraHolland U. A. Disponível em: <https:// www.royalfloraholland.com/en.>. Acesso em: $01 \mathrm{de}$ fev. 2018.

INSTITUTO BRASILEIRO DE FLORICULTURA - IBRAFLOR. Holambra. Disponível em: <http:// www.ibraflor.com/p_qualidade.php $>$. Acesso em: 04 de jan. 2018.

INTERNACIONAL PLANT GENETIC RESOURCES INSTITUTE - IPGRI. Descriptores para Capsicum - (Capsicum spp.). Roma, 1995. 51 p.

ISLA. Pimenta Ornamental. ISLA Sementes. Porto Alegre. Disponível em: <http://www.isla.com.br>. Acesso em: 13 de fev. 2018.

LORENZI, H.; SOUZA, H. M. Plantas ornamentais no Brasil: arbustivas, herbáceas e trepadeiras. 4. ed. Nova Odessa, SP: Instituto Plantarum, 2008. 1088 p.

MELO, L. F. et al. Potencial ornamental de acessos de pimenta. Ciência Rural, v. 44, n. 11, p. 20102015, 2014.

NASCIMENTO, N. F. F. et al. Intraespecific compatibility in ornamental pepper. Acta Horticulturae, v. 1087, n. 1, p. 339-344, 2015.

NEITZKE, R. S. et al. Dissimilaridade genética entre acessos de pimenta com potencial ornamental. Horticultura Brasileira, v. 28, n. 1, p. 47-53, 2010.

NEITZKE, R. S. et al. Pimentas ornamentais: aceitação e preferências do público consumidor. Horticultura Brasileira, v. 34, n. 1, p. 102-109, 2016.

REGG, E. R. et al. Inheritance for earliness in ornamental peppers (Capsicum annuum). Acta Horticulturae, v. 961, n. 1, p. 405-410, 2012.

SANTOS, R. M. C. et al. Ornamental pepper breeding: could a chili be a flower ornamental plant? Acta Horticulturae, v. 1000, n. 1, p. 451-456, 2013.

SCOTT, A. J.; KNOTT, M. A cluster analysis method for grouping means in the analysis of variance. Biometrics, v. 30, n. 3, p. 507-512, 1974.

SILVA, F. C. et al. Evaluation of substrates on the production of ornamental Capsicum. Acta Horticulturae, v. 1060, n. 1, p. 115-120, 2015.

STOMMEL, J. R.; BOSLAND, P. W. Ornamental pepper Capsicum annuum. In: ANDERSON, N. O. (Eds.). Flower Breeding and Genetics: Issues, 
Challenges, and Opportunities for the $21^{\text {st }}$ Century. Dordrecht, the Netherlands: Springer, p. 561-599, 2005.

STOMMEL, J. R.; GRIESBACH, R. J. Capsicum annuum L. 'Black Pearl'. HortScience, v. 40, n. 5, p. 1571-1573, 2005.

SUDRÉ, C. P. et al. Variáveis multicategóricas na determinação da divergência genética entre acessos de pimenta e pimentão. Horticultura Brasileira, v. 24, n. 1, p. $88-93,2006$

VASCONCELOS, C. S. et al. Determinação da dissimilaridade genética entre acessos de Capsicum chinense com base em características de flores.

Revista Ceres, v. 59, n. 4, p. 493-498, 2012.

VEILING HOLAMBRA. Critérios de classificação pimenta ornamental. Cooperativa Veiling Holambra: Santo Antônio de Posse, SP, 2018. Disponível em: <http://veiling.com.br/uploads/ padrao_qualidade/criterios/pimenta-ornamentalpo.pdf $>$. Acesso em: 04 de jan. 2018.

WITT, D. The chile pepper encyclopedia. New York: William Morrow and Company, 1999. 337 p. 